\title{
W poszukiwaniu odpowiedzi na pytanie - Czy nauczyciele gimnazjum kształtuja postawę ekologiczną swoich wychowanków?
}

W pierwszej dekadzie trzeciego tysiąclecia szczególnie ważnym zadaniem dla społeczności jest powstrzymanie degradacji środowiska i budowa nowego ładu społeczno - gospodarczego, przestrzegającego prawa przyrody.

Zaspokojenie aspiracji cywilizacyjnych i rozwojowych ludności ma być osiągnięte bez niszczenia zasobów naturalnych $\mathrm{z}$ zachowaniem bogactwa przyrody i trwałych wartości kultury dla następnych pokoleń. Młodzi ludzie a szczególnie młodzież szkół średnich protestuje przeciw niszczeniu środowiska, gdyż jest wrażliwa ma radykalne poglądy i przeświadczona, że przyroda dziś niszczona będzie już zniszczona dla przyszłych pokoleń. Pozytywny i odpowiedzialny stosunek do przyrody musi stać się trwałym elementem systemu wartości kształtującego kulturę człowieka. Wynika to z badań przeprowadzonych w latach 1995 -1996 wśród uczniów szkół średnich w Kielcach ${ }^{1}$. Potwierdza to wypowiedź Rutkowskego K. ${ }^{2}$, że młody człowiek powinien nie tylko wiedzieć, ale także rozumieć i w pewnym stopniu emocjonalnie „czućc dlaczego ochrona przyrody i środowiska jest tak ważna.

Problemem dla budowy i umacniania się trwałego, zrównoważonego rozwoju jest nadmierny konsumpcjonizm, nieoszczędne korzystanie z dóbr natury. Ważne okazują się codzienne zachowania człowieka, przejawiane we własnym gospodarstwie domowym. Mimo, że uczeń spędza większość czasu w domu to głównym źródłem wiedzy o środowisku jest szkoła.

Szerokie rzesze społeczne muszą zrozumieć, że możliwości ekosystemu Ziemi są ograniczone, a sam postęp cywilizacyjno-techniczny nie rozwiąże złożonych problemów środowiskowych. Potrzebne są nowe wzorce zachowań i podporząd-

Fudalı I. Kultura ekologiczna młodzieży. Wydawnictwo Akademii Świętokrzyskiej, Kielce 2002, s. 228-230.

2 Rutkowski K.: Realizacja zadań oświatowych z Agendy 21, [w:] red. D. Cichy: Edukacja środowiskowa Agenda 21-realizacja zadań edukacyjnych, IBE, Warszawa 1997, s. 17-18. 
kowanie działań wartościom istotnym dla zrównoważonego rozwoju. Ważne jest, aby ludzie wiedzieli jak żyć dzisiaj, a także w przyszłości i czym jest „dobre życie”.

Młode pokolenie jest nadzieją nadania sprawie ochrony przyrody i środowiska odpowiedniej rangi w przyszłości.

Warunkiem zrozumienia środowiska jest jego poznanie. Đylko gruntowna wiedza na temat praw obowiązujących w przyrodzie oraz zależności i mechanizmów decydujących o stanie środowiska umożliwi podejmowanie właściwych decyzji służących jego ochronie. Wychodząc z założenia, że trwały i zrównoważony rozwój jest jedyną alternatywą przetrwania ludzkości, edukacja ekologiczna stanowić powinna jedno z głównych zadań szkoły. Polska szkoła daleka jest od realizacji tego założenia. W polskim systemie kształcenia ogólnego edukacja środowiskowa, na wszystkich poziomach, traktowana jest marginalnie. Brak integracji treści dotyczących ochrony środowiska powoduje ich rozdrobnienie i nie sprzyja kształtowaniu odpowiedniego poziomu świadomości ekologicznej. ${ }^{3}$

Zagadnienie postaw moralnych w działaniu człowieka i społeczeństwa w myśl zasad zrównoważonego rozwoju podejmowane jest w takich naukach jak etyka środowiska, ekofilozofia, edukacja środowiskowa. Edukacja środowiskowa - wyrażenie to coraz powszechniej używane w szkolnictwie odnosi się do treści zawartych w pojęciach; edukacja ekologiczna i edukacja sozologiczna oraz pewne aspekty samego terminu szeroko rozumianego środowiska. Jak zauważa Dołęga ${ }^{4}$ w edukacji ekologicznej bardzo ważną rolę mają tak zwane nauki ekologiczne, które dostarczają podstawowej informacji naukowej z wielu ważnych obszarów składających się na strukturę środowiska.

Przez edukację rozumiemy ${ }^{5}$ - (łac. educatio - wychowanie), ogół procesów i oddziaływań, których celem jest zmienianie ludzi, przede wszystkim dzieci i młodzieży - stosownie do panujących w danym społeczeństwie ideałów i celów wychowawczych. Znaczenie terminu edukacja było chwiejne; jedni kojarzyli go $\mathrm{z}$ wykształceniem inni z wychowaniem. Obecnie upowszechnia się szerokie rozumienie tego terminu jako oznaczającego ogół procesów oświatowo - wychowawczych, obejmujących kształcenie i wychowanie oraz szeroko pojmowaną oświatę ${ }^{6}$.

KowALAK A.: Wspomaganie edukacji ekologicznej w szkołach przez realizację projektów, [w:] red. D. CIcHY: Edukacja środowiskowa wzmocnieniem zrównoważonego rozwoju, IBE, Warszawa, 2005, s. 280.

4 DoŁĘGA J.: Znaczenie postaw moralnych spoleczeństwa we wdrażaniu zasad zrównoważonego rozwoju, [w:] red. D. CicHY: Edukacja środowiskowa wzmocnieniem zrównoważonego rozwoju, IBE, Warszawa 2005, s. 7-11

5 OKoń W: Nowy stownik pedagogiczny, Wydawnictwo Akademickie ŻAK, Warszawa 2004, s. 93.

6 BaRAnIAK B.: Typologia programów kształcenia, [w:] red. D. CichY: Edukacja środowiskowa. Programy. Metody. Efekty. Zeszyty Naukowe 28, Polska Akademia Nauk Komitet „Człowiek i Şrodowisko" przy Prezydium PAN, IBE, Warszawa 2002, s. 44. 
Edukacja koncentruje swoją uwagę na procesie stawania się i bycia człowiekiem, odpowiednio do wizji wyznaczonej przez filozofię ${ }^{7}$.

Młodzież gimnazjum aktywnie uczestniczy w różnych formach działań, jeśli jest odpowiednio umotywowany cel działania. W tym jest bardzo duża rola nauczyciela jako osoby kierującej działalnością uczniów. Wyniki badań wśród uczniów uczestniczących w różnego rodzaju innowacjach pedagogicznych odnośnie stanu wiadomości, zdobytych umiejętności, poglądów i postaw w porównaniu do grup kontrolnych bądź przed i po zakończeniu działań są zadawalające i wskazują, że takie formy pracy wpływają na rozwój zainteresowań, wyższy poziom wiadomości i poprawnie kształtują świadomość ekologiczną. Potwierdzają to wyniki badań prowadzonych między innymi przez Parka i Żeber - Dzikowska Bobrzyńska ${ }^{9}$, Kowalak ${ }^{10}$, Stańczak ${ }^{11}$.

Współczesny nauczyciel zajmuje newralgiczną pozycję w kulturze; jest pomostem między światem myśli a powszechną świadomością szerokich rzesz ludzkich. Jest to pozycja odpowiedzialna. Wymaga rzetelnych kwalifikacji zwłaszcza intelektualnych. Miejsce nauczyciela w kulturze wynika z konieczności sprostania nowemu układowi odniesienia czyli procesów zmienności świata, pojawiania się i kumulacji kryzysów wyrażającym się w zamęcie aksjologicznym, pojawianiem się rozmaitych nurtów poznawczych, fizjologicznych i kulturowych. Konstruktywne odnalezienie się w tym świecie wymaga innych kompetencji poznawczych i sprawnościowych niż oferuje nauczycielowi system edukacji. Jeśli nauczyciel chce czynić, aby świat był zrozumiały, to w pierwszym rzędzie sam musi go zrozumieć, sprawnie odczytywać otaczającą go rzeczywistość i być obiektywnym tłumaczem tego świata ${ }^{12}$.

7 Bogaj A.: Wspótczesne teorie edukacji a struktura programów nauczania, [w:] red. D. CICHY: Edukacja Srodowiskowa. Programy. Metody. Efekty, Zeszyty Naukowe 28, Polska Akademia Nauk Komitet „Człowiek i Srodowisko” przy Prezydium PAN, IBE, Warszawa 2002, s. 16.

8 PARKa B., ŻEBer-Dzikowska I.: Edukacja dla zrównoważonego rozwoju-formy realizacji w świetle badań, [w:] red. D. CicHY: Edukacja środowiskowa wzmocnieniem zrównoważonego rozwoju, IBE, Warszawa 2005, s. 196.

9 BobrzyŃska E.: Kształtowanie postaw dla ochrony różnorodności biologicznej, [w:] red. D. Cichy: Edukacja środowiskowa wzmocnieniem zrównoważonego rozwoju, Warszawa 2005, s. 203.

10 Kowalak A.: Efekty polsko - slowackiego programu edukacji ekologicznej „Zielone Karpaty”, red. D. Cichy: Edukacja środowiskowa wzmocnieniem zrównoważonego rozwoju, IBE, Warszawa 2005, s. 217.

11 Stańczak M.: Realizacja projektu „Przyroda wokót nas” [w:] red. D. CichY: Edukacja środowiskowa wzmocnieniem zrównoważonego rozwoju, Warszawa 2005, s. 165.

12 Kwiatkowska H.: Intelektualność kwalifikacji zawodowych nauczyciela, red. H. Kwiatkowska, M. Szy bisz: Edukacja i dialog w świecie przyszłości, Wyższa Szkoła Humanistyczna im. A. Gieysztora, Pultusk 2003, s. 101. 
Od nauczyciela wymaga się większej samodzielności i umiejętności korzystania $\mathrm{z}$ uzyskanej autonomii w zakresie doboru procedur osiągania celów na poziomie wiadomości, umiejętności i postaw. Nauczyciel nie tylko "realizuje” program nauczania ale także go tworzy, adaptuje i rozszerza. Współcześni nauczyciele, a szczególnie nauczyciele przedmiotów przyrodniczych muszą posiadać wiele nowych niż dotychczas kompetencji: bardziej łącznych niż wąsko specjalistycznych, bardziej otwartych niż zamkniętych, bardziej twórczych niż odtwórczych. Nauczanie jest dziedziną zawodowo praktyczną, czyli wymaga kreatywności i ekspresji ze strony nauczyciela. Nauczyciele przyrodnicy to refleksyjni praktycy, przewodnicy w poznawaniu wiedzy i entuzjaści sukcesu swoich wychowanków ${ }^{13}$.

Integracja międzyprzedmiotowa nie polega na nauczaniu przekrojowym, ale na interdyscyplinarnym ujmowaniu podstawowych problemów przyrodniczych, przekraczaniu granic poszczególnych dyscyplin w stopniu pozwalającym na wieloaspektowe spojrzenie na problem i wskazanie możliwości praktycznego rozwiązania problemu. Znajomość ekologii daje podstawę do holistycznego spojrzenia na przyrodę, zrozumienia jej struktury i zachodzących procesów, stanowi równocześnie podstawę zrozumienia funkcjonowania krajobrazów i efektów antropopresji, zasad szeroko pojętej ochrony przyrody i środowiska oraz idei ekorozwoju ${ }^{14}$.

Aby przygotować młodych ludzi do radzenia sobie z problemami współczesnego świata i realizacją zadań dla zrównoważonego rozwoju, jak wspomniano wcześniej, wymaga to od samego nauczyciela szerokich kompetencji, twórczej i innowacyjnej postawy. Zakres kompetencji, którymi powinien charakteryzować się nauczyciel przygotowujący młodzież do zadań z zakresu zrównoważonego rozwoju przedstawiono w tabeli $\mathrm{nr} 1$.

13 JagodzińsKa M.: Ksztalcenie przyrodnicze w szkole podstawowej. Przygotowanie nauczycieli do edukacji przyrodniczej. ODN, Płock 2005, s. 9-10.

14 Ciesielska Z.: Przygotowanie nauczycieli do zintegrowanego nauczania, [w:] red. D. CICHY: Nauczyciel 2000-plus. Modernizacja kształcenia nauczycieli przyrody, biologii i ochrony środowiska, IBE, Warszawa 2001, s. 42-48. 
Tabela nr 1. Kompetencje nauczyciela prowadzacego edukację dla ekorozwoju. (źródto Tkaczyk, 2004¹5).

\begin{tabular}{|c|c|c|}
\hline $\begin{array}{l}\text { Ogólnozawodowe } \\
\text { (globalne) }\end{array}$ & Etyczne & $\begin{array}{c}\text { Profesjonalno-programowe } \\
\text { wg Kwiatkowskiej - Kowal (1994) }\end{array}$ \\
\hline $\begin{array}{l}\text { 1. Likwidowanie anal- } \\
\text { fabetyzmu. } \\
\text { 2. Zapewnienie dostę- } \\
\text { pu do wiedzy. } \\
\text { 3. Autonomia i wol- } \\
\text { ność w systemie eduka- } \\
\text { cji } \\
\text { 4. Kształtowanie war- } \\
\text { tości uniwersalnych } \\
\text { 5. Wychowywanie do } \\
\text { tolerancji } \\
\text { 6. Wdrażanie do demo- } \\
\text { kracji uczestniczącej } \\
\text { 7. Wdrażanie do } \\
\text { ochrony i wspomagania } \\
\text { zdrowia } \\
\text { 8. Kształtowanie świa- } \\
\text { domości o konieczności } \\
\text { wprowadzenia w życie } \\
\text { zasad ekorozwoju }\end{array}$ & $\begin{array}{l}\text { 1. Autorytet } \\
\text { 2. Sprawiedliwość } \\
\text { 3. \olerancja } \\
\text { 4. Obowiązkowość } \\
\text { 5. Kultura ekolo- } \\
\text { giczna } \\
\text { 6. Godność } \\
\text { 7. Wolność } \\
\text { 8. Wytrwałość } \\
\text { 9. Rozsądek } \\
\text { 10. Uczciwość } \\
\text { 11. Prostolinijność } \\
\text { 12. Kreatywność } \\
\text { 13. Przekonanie } \\
\text { o konieczności } \\
\text { wprowadzenia w ży- } \\
\text { cie zasad ekorozwo- } \\
\text { ju }\end{array}$ & $\begin{array}{l}\text { 1. W zakresie zadań orientacyjnych: } \\
\text { - orientacja w podstawowych aktach praw- } \\
\text { nych, podstawach programowych, podręczni- } \\
\text { kach i środkach dydaktycznych } \\
\text { - świadomość celów edukacji środowiskowej } \\
\text { 2. W zakresie zadań decyzyjnych: } \\
\text { - kompetencje do wyboru programu naucza- } \\
\text { nia, podręcznika i środków dydaktycznych } \\
\text { - kompetencje do prowadzenia projektów } \\
\text { i ścieżek edukacyjnych } \\
\text { - umiejętność planowania pracy dydaktycz- } \\
\text { no-wychowawczej oraz projektowania form } \\
\text { i metod pracy w realizacji celów edukacyjnych } \\
\text { 3. W zakresie zadań wykonawczych: } \\
\text { - umiejętność wyprowadzania celów szczegó- } \\
\text { łowych z kierunkowych celów nauczania } \\
\text { - umiejętność dostosowania wiedzy do per- } \\
\text { cepcji uczniów } \\
\text { - tworzenie warunków do realizacji założo- } \\
\text { nych celów } \\
\text { - zdolność do podejmowania działań inno- } \\
\text { wacyjnych } \\
\text { - umiejętność prowadzenia ewaluacji sku- } \\
\text { teczności procesu dydaktyczno-wychowawcze- } \\
\text { go oraz dokonywanie skutecznej korekty. }\end{array}$ \\
\hline
\end{tabular}

Interdyscyplinarna prezentacja problemów z zakresu ekologii i ochrony środowiska w myśl zasad zrównoważonego rozwoju z podejmowaniem prób rozwiązywania ich w skali lokalnej oraz $\mathrm{z}$ uwzględnieniem regionalnych uwarunkowań społecznych i kulturowych w szkole nie jest łatwa. Przede wszystkim nasuwa się pytanie: „Czy nauczyciele zostali do nich odpowiednio przygotowani?”

W poszukiwaniu odpowiedzi na to pytanie w latach 2005-2006 przeprowadzono badania na grupie 360 nauczycieli uczących w gimnazjach, podlegających nadzorowi pedagogicznemu Kuratora Oświaty w Warszawie Delegatury w Płocku. W badaniach posłużono się kwestionariuszem ankiety i wywiadu, który został ustalony na podstawie badań pilotażowych przeprowadzonych we wrześniu 2004 roku na grupie 20 nauczycieli.

15 囚КасZYк L.: Rola nauczyciela w procesie ksztaltowania postaw młodzieży, [w:] Edukacja Biologiczna i Środowiskowa nr 2-3, 2004. 
Badania, których wyniki zamieszczono w niniejszym opracowaniu, objęly nauczycieli różnych przedmiotów, nie tylko przyrodników. Zastosowano metodę sondażu diagnostycznego, technikę wywiadu i ankiety.

\section{CEL I OPIS BADAŃ}

Celem badań była charakterystyka procesu edukacji ekologicznej oraz przygotowanie nauczycieli do prowadzenia edukacji w kierunku zrównoważonego rozwoju.

W badaniach wzięło udział 360 nauczycieli w tym 11 mężczyzn co stanowi 3\% i 349 kobiet tj. 97\%. Pracują oni na pełnych etatach i posiadają wyższe wykształcenie.

Długość stażu pracy przedstawia się następująco $(\mathrm{N}=360)$;

1. $0-5$ lat $-28 \%$

2. 6-10 lat $-19 \%$

3. $11-20$ lat $-25 \%$

4. powyżej 20 lat $-28 \%$

Badaną grupę przedmiotową stanowili nauczyciele następujący przedmiotów;

Tabela 2. Nauczane przedmioty przez nauczycieli objętych badaniami.(źródło wlasne)

\begin{tabular}{|l|c|c|}
\hline \multicolumn{1}{|c|}{ Nauczany przedmiot } & $\mathrm{N}$ & $\%$ \\
\hline biologia & 135 & 37,5 \\
\hline geografia & 34 & 9,4 \\
\hline chemia & 23 & 6,3 \\
\hline fizyka & 11 & 3.1 \\
\hline matematyka & 23 & 6,3 \\
\hline język. polski & 56 & 15,6 \\
\hline historia & 22 & 6,2 \\
\hline języki obce & 34 & 9,4 \\
\hline Inne przedmioty & 22 & 6,2 \\
\hline
\end{tabular}

Wszyscy ankietowani nauczyciele potwierdzili, że wybrane przez nich programy nauczania zawierają treści o tematyce ekologicznej i sozologicznej w różnym wymiarze:

- 37,5\% nauczycieli uważa, że treści ekologiczne są omawiane w wystarczającym wymiarze,

- $62,5 \%$ twierdzi, że w małym wymiarze.

Przedstawia się to następująco: 


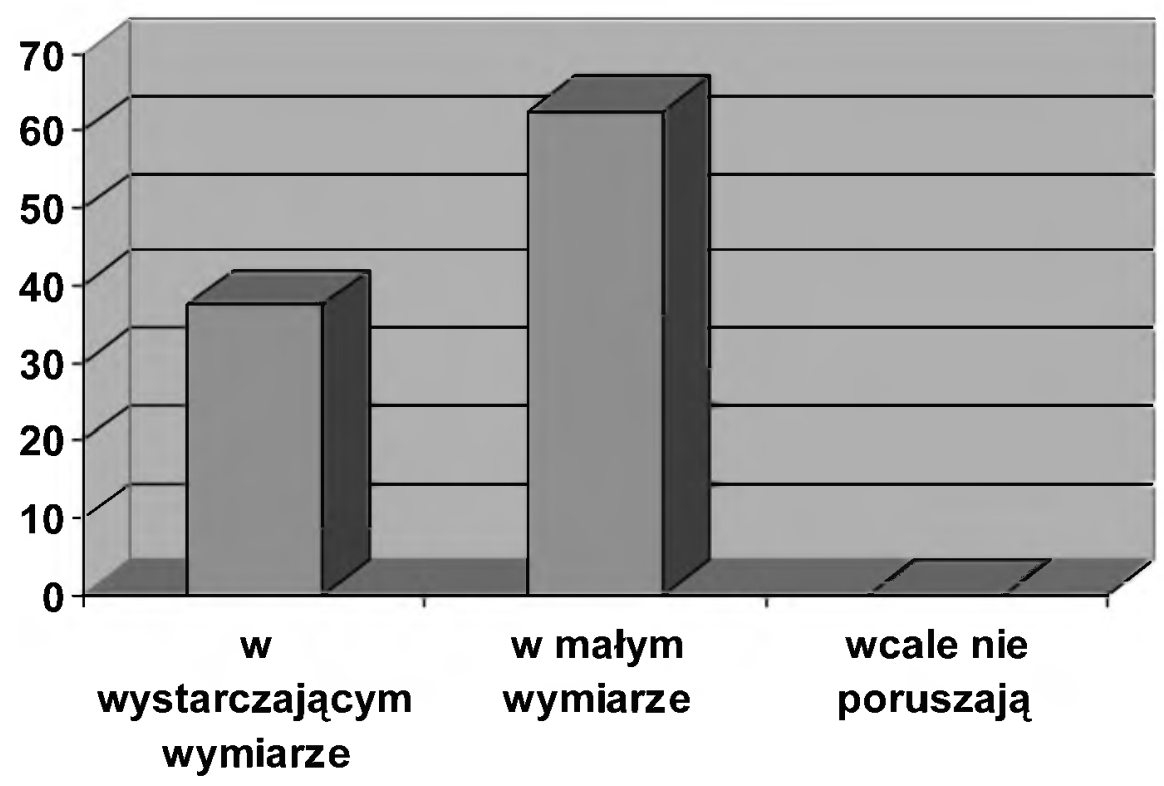

Wykres 1. Zawartość treści ekologicznych w wybieranych programach nauczania w ocenie nauczycieli (wskániki w\%) (źródlo, badania własne 2005-2006)

Nauczyciele redagują cele operacyjne, konstruują lub korzystają z opracowanych planów wynikowych ponieważ ułatwia im to pracę i jasno precyzuje dzialania w czasie zajęć.

$25 \%$ respondentów stwierdziło, że nie konstruuje planów wynikowych i nie precyzuje celów operacyjnych.

Doświadczenia, eksperymenty i obserwacje to jedne z metod badawczych, które prowadzą do wyjaśnienia procesów biologicznych, zjawisk przyrodniczych na naukowych podstawach. Pozwala to na przeżywanie i odbiór natury oraz na rozwój sfery emocjonalnej i odpowiednich postaw w stosunku do przyrody. Okazuje się, że uczniowie nie wykonują doświadczeń i eksperymentów. Przeważnie obserwują lub analizują gotowe wyniki.

59\% nauczycieli podało, że ich uczniowie nie wykonują doświadczeń i eksperymentów a 11,8\% twierdzi, że uczestniczą rzadko.

Obrazuje to wykres 2. 


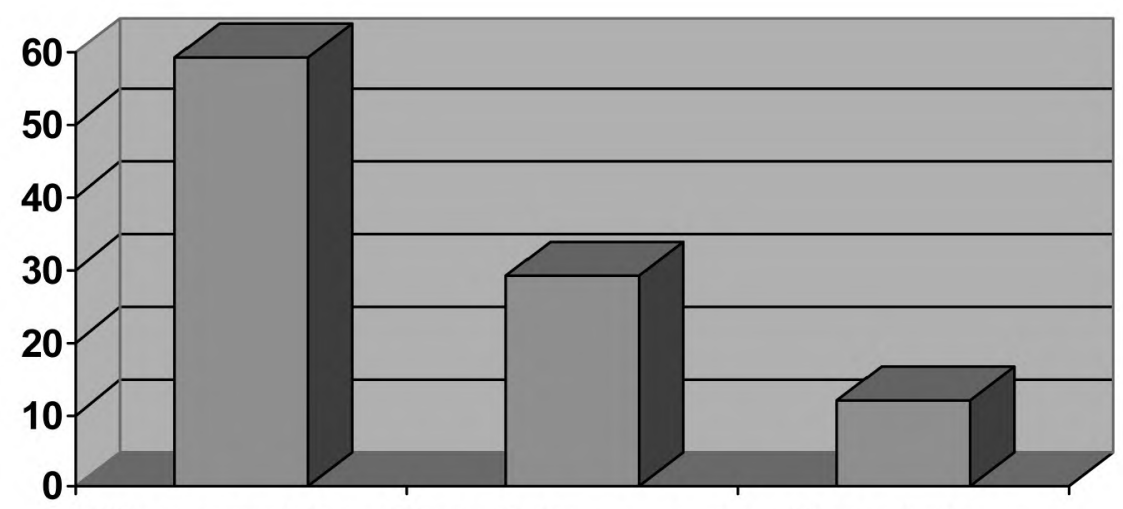

Nie uczestniczą Uczestniczą często Uczestniczą

rzadko

Wykres 2. Uczestnictwo uczniów w doświadczeniach i eksperymentach. (wskaźniki w\%) (źródto, badania wlasne 2005-2006)

Uczniowie, którzy aktywnie uczestniczą w zajęciach z zakresu edukacji ekologicznej najczęściej prowadzą:

1. Monitoring najbliższej okolicy zanieczyszczeniami tlenkami siarki $\mathrm{z}$ wykorzystaniem skali porostowej.

2. Lokalizację punktów skupu surowców wtórnych.

3. Segregacje odpadów.

4. Określają zanieczyszczenie środowiska w miejscu zamieszkania.

Zajęcia te prowadzą $\mathrm{z}$ reguły nauczyciele $\mathrm{z}$ ponad 15 letnim stażem pracy. 75\% Ankietowanych nauczycieli stwierdziło, ze nie uczestniczyło w formach doskonalenia dotyczących zrównoważonego rozwoju.

Wiedzę na temat zrównoważonego rozwoju, oprócz tej zdobytej w toku studiów przedmiotowych nauczyciele czerpią z;

1. internetu

2. podręczników akademickich

3. prac uczniów

4. poradników metodycznych

5. filmów

6. prasy naukowej i nauczanego przedmiotu

7. czasopism o tematyce ekologicznej np. Przyroda Polska, Aura.

Zdecydowanie w wypowiedziach respondentów najczęściej pojawiał się internet.

37\% nauczycieli, przeważnie biologii i geografii w nauczaniu o zrównoważonym rozwoju stosuje projekty edukacyjne. (wykres 3 ) 


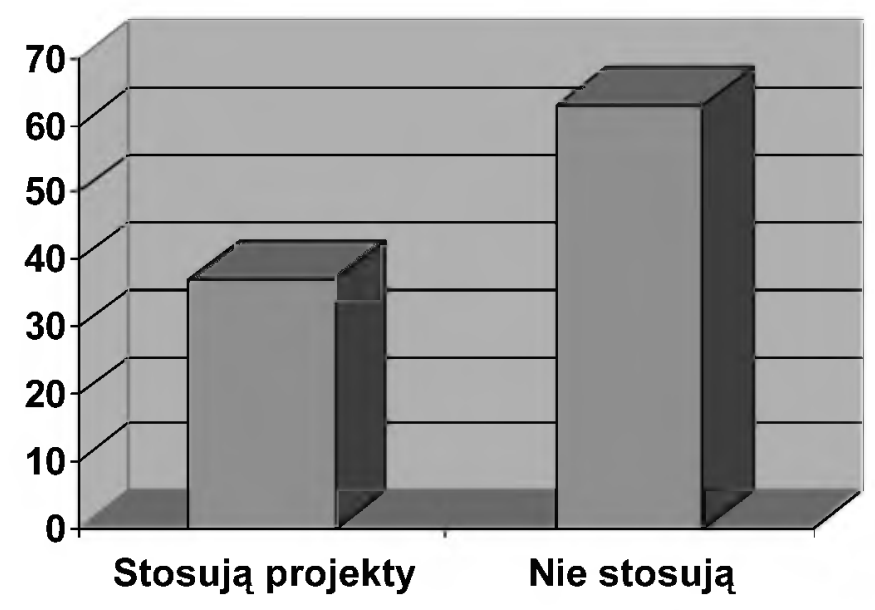

Wykres 3. Stosowanie projektów edukacyjnych w nauczaniu o zrównoważonym rozwoju-N=360, (wskaźniki w\%), (źódlo, badania wlasne 2005-2006)

Najczęściej są to projekty:

1. Rady na odpady.

2. Przyroda naszej gminy.

3. Przyroda wokół nas.

4. Pomniki przyrody najbliższej okolicy.

5. Cudze chwalicie swego nie znacie.

Projekty te nie są wspierane dotacjami grantowymi Urzędu Miasta lub Urzędu Gminy bądź z innych źródeł.

$11,8 \%$ nauczycieli podało, że opracowuje wnioski o dofinansowanie przy realizacji projektów edukacyjnych. Ubieganie się o dofinansowanie związane jest $\mathrm{z}$ dodatkową pracą przy wypełnianiu wniosków, kompletowaniu niezbędnej dokumentacji.

Uczniowie chętnie biorą udział w konkursach o tematyce ekologicznej. W przygotowaniu merytorycznym wspierają ich nauczyciele. \akie działania deklaruje 56\% nauczycieli (wykres 4). 


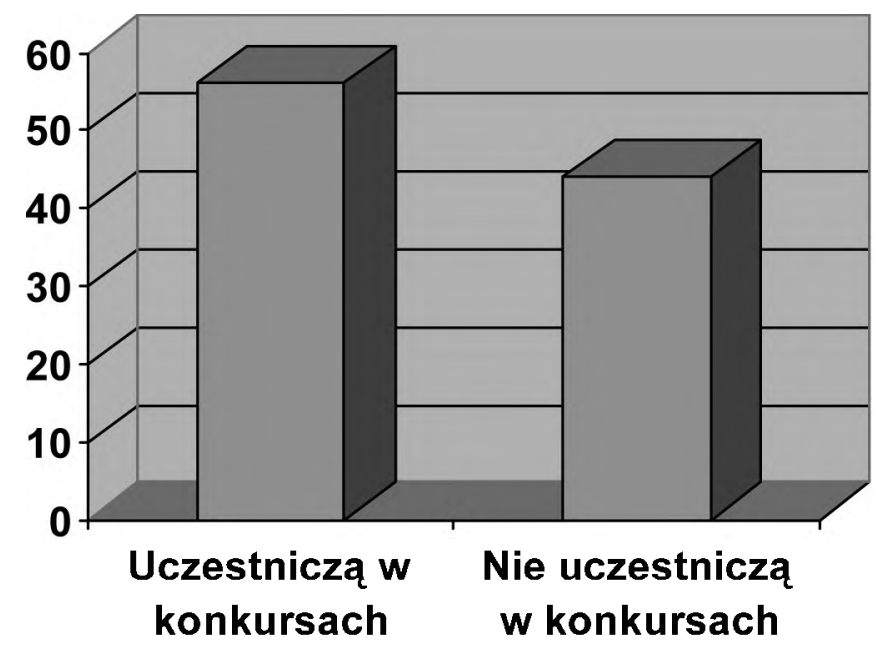

Wykres 4. Przygotowanie uczniów do uczestnictwa w konkursach o tematyce ekologicznej.(wskaźniki w\%) (źródto, badania wlasne 2005-2006)

冈ematyka konkursów sprowadza się do:

1. Woda jest życiem.

2. Olimpiady wiedzy ekologicznej.

3. Konkursy tematyczne - woda, gleba, atmosfera.

4. Konkursy plastyczne i fotograficzne.

$87 \%$ ankietowanych nauczycieli twierdzi, że realizacja zagadnień ekologicznych i sozologicznych nie sprawia im trudności. Zastanawiający jest fakt, ze ci sami nauczyciele odpowiadając po trzech miesiącach na pytania $w$ kwestionariuszu wywiadu poproszeni o zdefiniowanie pojęcia „zrównoważony rozwój” tylko w 33,3\% udzielili poprawnej odpowiedzi (tabela 3).

Tabela 3: Poprawność interpretacji pojęcia „zrównoważony rozwój” w grupach przedmiotowych. (źródło, badania własne 2005-2006)

\begin{tabular}{|c|c|c|c|c|c|c|c|c|}
\hline \multirow{2}{*}{$\begin{array}{l}\text { Zdefiniowanie pojęcia } \\
\text { „Zrównoważony rozwój }\end{array}$} & \multicolumn{2}{|c|}{$\begin{array}{c}\text { nauczyciele } \\
\text { biologii }\end{array}$} & \multicolumn{2}{|c|}{$\begin{array}{c}\text { nauczyciele } \\
\text { geografii }\end{array}$} & \multicolumn{2}{|c|}{$\begin{array}{c}\text { nauczyciele } \\
\text { historii }\end{array}$} & \multicolumn{2}{|c|}{$\begin{array}{c}\text { pozostali nauczy- } \\
\text { ciele }\end{array}$} \\
\hline & $\mathrm{N}=135$ & $\%$ & $\mathrm{~N}=34$ & $\%$ & $\mathrm{~N}=22$ & $\%$ & $\mathrm{~N}=169$ & $\%$ \\
\hline $\begin{array}{l}\text { Odpowiedź prawidło- } \\
\text { wa- bardzo dobra }\end{array}$ & 135 & 100 & 34 & 100 & 4 & 18,2 & 1 & 0,59 \\
\hline Odpowiedź błędna & 0 & 0 & 0 & 0 & 15 & 68,2 & 110 & 65,1 \\
\hline Brak odpowiedzi & 0 & 0 & 0 & 0 & 3 & 13,6 & 58 & 34,31 \\
\hline
\end{tabular}


W dalszej części wywiadu, kiedy pominięto pojęcie „zrównoważony rozwój” a pytania dotyczyły treści ekologicznych nauczyciele prawidłowo dostrzegali zależności występujące $w$ treściach nauczanego przedmiotu a edukacją ekologiczną.

Proszeni o wskazanie trudności jakie występują w kształceniu uczniów gimnazjum dla zrównoważonego rozwoju tylko nauczyciele biologii i geografii wskazywali na konkretne trudności. Są to:

1. Zbyt mała tygodniowa liczba godzin $\mathrm{z}$ biologii i geografii.

2. Zbyt dużo zagadnień i problemów do omówienia.

3. Zbyt liczne klasy szczególnie w gimnazjach miejskich.

4. Brak możliwości zorganizowania zajęć terenowych, wyjazdowych, biwaków ekologicznych.

5. Brak zainteresowania problemami ochrony przyrody, środowiska młodzieży gimnazjalnej.

W tym miejscu bardzo cenne są uwagi nauczyciela historii, który wskazał na:

1. Brak korelacji z przedmiotem historii.

2. W podręcznikach do historii w niewielkim stopniu zwraca się uwagę na aspekt ekologiczny.

3. Opracowanie materiałów o tematyce ekologicznej w kontekście kształcenia historycznego np. Skutki ekologiczne rozwoju przemysłu w XIX wieku. lub Zagadnienia gospodarki naturalnej i jej zalety $z$ wykorzystaniem dawnych metod upraw i przetwórstwa $w$ dzisiejszych czasach.

\section{Podsumowanie}

Przedstawione wyniki badań przeprowadzone wśród nauczycieli gimnazjum $\mathrm{w}$ aspekcie nauczania o zrównoważonym rozwoju są $\mathrm{w}$ dalszym ciągu nie zadawalające. Podstawowym, najważniejszym problemem jest niezrozumienie przez liczną grupę nauczycieli - 67\% pojęcia „zrównoważony rozwój”.

Mimo, że respondenci uważają iż nie mają problemów z nauczaniem treści o tematyce ekologicznej, to zestawienie odpowiedzi kwestionariusza ankiety i wywiadu jest wymowne.

Ankietowani nauczyciele wybierają programy nauczania w których omawiane są zagadnienia o tematyce ekologicznej aczkolwiek w niektóry przypadkach są to namiastki edukacji ekologicznej. Przykładem może być np. język polski. Nauczyciel jako przykład zadania praktycznego należącego do zagadnień ekologicznych podaje redagowanie ogłoszenia lub zaproszenia. 
Uzyskane w niniejszych badaniach wyniki są zgodne z wynikami prezentowanymi przez licznych autorów takich jak; $₫$ kaczyk L. ${ }^{16}$, Cichy D ${ }^{17}$, \uszyńska L. ${ }^{18}, \mathrm{i}$ innych.

Na podstawie przedstawionych wyników badań należy wnioskować:

- Edukacja nie nadąża za oczekiwaniami społecznymi i wymaganiami czasu.

- Nauczyciele jak i młodzież powinni zostać wyposażeni w wiadomości i umiejętności, które pomogą aktywnie rozwiązywać problemy środowiskowe i umacniać poczucie odpowiedzialności za stan środowiska.

- Poznanie wszystkich działań w zakresie zrównoważonego rozwoju powinno być dokładnie omówione na konkretnych przykładach a nie tylko korzystając z definicji z podręcznika.

- Aby wiadomości i umiejętności zostały prawidłowo zastosowane, by w prawidłowy sposób była kształtowana postawa ekologiczna młodych ludzi potrzeba, aby osoba - nauczyciel, który wprowadza w zagadnienia zrównoważonego rozwoju swojego wychowanka, sam rozumiał istotę problemu i konieczność prowadzenia zadań edukacyjnych.

- Należy zastanowić się nad koncepcją kształcenia nauczycieli w kierunku strategii dla zrównoważonego rozwoju i dążyć do wprowadzenia obowiązkowych zajęć z zakresu edukacji ekologicznej w myśl zasad zrównoważonego rozwoju.

\section{LITERATURA}

Baraniak B., Typologia programów ksztatcenia. [w:] red. D. Cichy: Edukacja Srodowiskowa. Programy. Metody. Efekty.Zeszyty Naukowe 28, Polska Akademia Nauk Komitet „Człowiek i Şrodowisko", przy Prezydium PAN, IBE, Warszawa 2002.

BoBRzYŃska E.: Kształtowanie postaw dla ochrony różnorodności biologicznej. [w:] red. D. CICHY: Edukacja środowiskowa wzmocnieniem zrównoważonego rozwoju. Warszawa 2005.

Bogaj A.: Wspótczesne teorie edukacji a struktura programów nauczania. [w:] red. D. CicHY: Edukacja Srodowiskowa. Programy. Metody. Efekty. Zeszyty Naukowe 28, Polska Akademia Nauk Komitet, Człowiek i Środowisko", przy Prezydium PAN, IBE, Warszawa 2002.

CIcHY D., Szkoła wobec wyznań edukacji biologicznej iśrodowiskowej w XXI wieku. IBE, Warszawa 2003.

Ciesielska Z.: Przygotowanie nauczycieli do zintegrowanego nauczania. [w:] red. D. Cichy: Nauczyciel 2000 - plus. Modernizacja kształcenia nauczycieli przyrody, biologii i ochrony środowiska. IBE, Warszawa 2001.

16 冈касzук Nauczyciele szkół ponadpodstawowych wobec edukacji srodowiskowej. [w:] red. D. Ciсну: Edukacja środowiskowa. Programy. Metody. Efekty. Zeszyty Naukowe 28, Polska Akademia Nauk Komitet „Człowiek i Środowisko”, przy Prezydium PAN, IBE, Warszawa 2002, s. $160-165$

17 Cichy D.: szkola wobec wyznań edukacji biologicznej i środowiskowej w XXI wieku, IBE, Warszawa 2003, s. 105-113.

18 冈uszYŃsKa L.: Strategia zrównoważonego rozwoju w świadorności warszawskich nauczyciel, [w:] red. D. CicHY: Edukacja środowiskowa wzmocnieniem zrównoważonego rozwoju, IBE, Warszawa 2005, s. 148-149. 
DoŁĘGA J.: Znaczenie podstaw moralnych spoleczeństwa we wdrażaniu zrównoważonego rozwoju. [w:] red. D. CICHY: Edukacja środowiskowa wzmocnieniem zrównoważonego rozwoju. IBE, Warszawa 2005.

FUDALI I. Kultura ekologiczna młodzieży. Wydawnictwo Akademii Świętokrzyskiej, Kielce 2002.

JAGODZIŃsKa M.: Ksztalcenie przyrodnicze w szkole podstawowej. Przygotowanie nauczycieli do edukacji przyrodniczej. ODN, Płock 2005.

KoWALAK A.: Wspomaganie edukacji ekologicznej w szkolach przez realizacje projektów. [w:] red. D. CIcHY, Edukacja środowiskowa. Założenia i rzeczywistość po reformie szkolnej. Zeszyty Naukowe 31, Polska Akademia Nauk Komitet "Człowiek i Środowisko”, przy Prezydium PAN, IBE, Warszawa 2002.

KowALAK A.: Efekty polsko-stowackiego programu edukacji ekologicznej „Zielone Karpaty”. [w:] red. D. CIсHY: Edukacja środowiskowa wzmocnieniem zrównoważonego rozwoju. IBE, Warszawa 2005.

KwIATKowska H.: Intelektualność kwalifikacji zawodowych nauczyciela. [w:] red. H. Kwiatkowska, M. Szy BISZ: Edukacja i dialog w świecie przyszłości. Wyższa Szkoła Humanistyczna im. A. Gieysztora, Pułtusk 2003.

Окоќ W.: Nowy stownik pedagogiczny. Wydawnictwo Akademicki ŻAK, Warszawa 2004.

PARKA B., ŻEBer-DzIKowsKa I.: Ewaluacja dla zrównoważonego rozwoju-formy realizacji w świetle badań. [w:] red. D. Cichy: Edukacja środowiskowa wzmocnieniem zrównoważonego rozwoju. IBE, Warszawa 2005.

RutKowski K.: Realizacja zadań oświatowych wynikających z Agendy 21. [w:] red. D. Cichy: Edukacja środowiskowa Agenda 21 - realizacja zadań edukacyjnych. IBE, Warszawa 1997.

STańczaK M.: Realizacja projektu „Przyroda wokól nas”. [w:] red. D. CIchy: Edukacja środowiskowa wzmocnieniem zrównoważonego rozwoju. IBE, Warszawa 2005.

Фкасzүк L.: Nauczyciele szkól ponadpodstawowych wobec edukacji środowiskowej. [w:] red. D. Ciсну: Edukacja środowiskowa-programy, metody, efekty. Zeszyty Naukowe 28, Polska Akademia Nauk Komitet „Człowiek i Şrodowisko”, przy Prezydium PAN, IBE, Warszawa 2002.

冈кACZYK L.; Rola nauczyciela w procesie ksztaltowania postaw młodzieży [w:] Edukacja Biologiczna i Środowiskowa nr 2-3. 2004.

\UszyŃsKa L.: Strategia zrównoważonego rozwoju w świadomości Warszawskich nauczycieli. [w:] red. D. CichY: Edukacja środowiskowa wzmocnieniem zrównoważonego rozwoju. IBE, Warszawa 2005. 


\title{
In search of answer to the question - Do teachers from grammar schools shape their pupils' ecologically friendly attitude?
}

\author{
SUMMARY
}

In order to survive humankind needs ecological education in accordance with the rule of well-balanced development. This phenomenon involves all educational processes. We need well-qualified teachers in order to mobilize pupils for proper action, influence their interests and higher level of knowledge or shape ecological awareness. These teachers link the world of thoughts and general consciousness.

The present study is the attempt to answer the question - Do teachers from grammar schools shape their pupils' ecologically friendly attitude?

P.S Has got acquainted with the girl, http://cyberblady.com, how it to you? Only it is fair! P.S Has got acquainted with the girl, http://cyberblady.com, how it to you? Only it is fair!

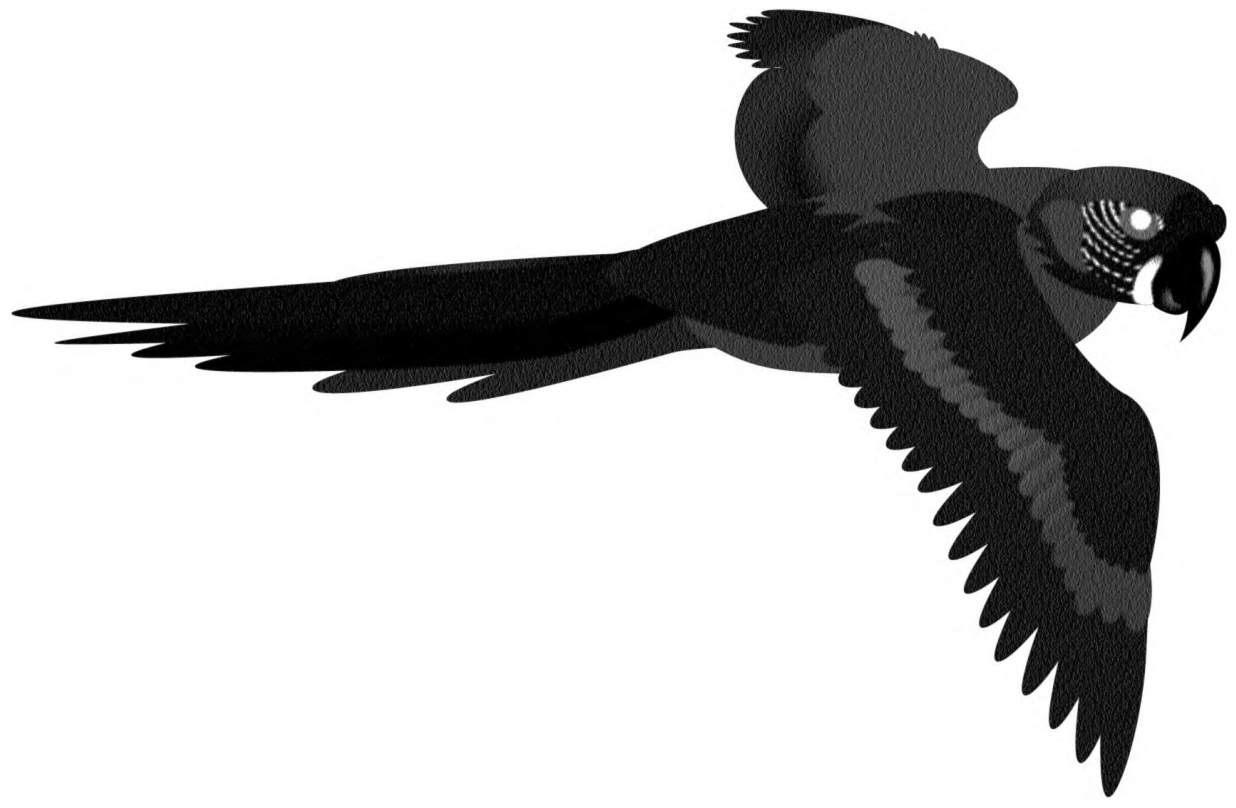

